\title{
Gene transfer in the aquatic environment: persistence and mobilization of the catabolic recombinant plasmid pD10 in the epilithon
}

\author{
Katja E. Hill, John C. Fry and Andrew J. Weightman
}

Author for correspondence: Katja E. Hill. Tel: +44222 874000 ext. 6002. Fax : +44222874305.

School of Pure and Applied Biology, University of Wales College of Cardiff, PO Box 915, Cardiff CF1 3TL, UK
This study investigated mobilization and persistence of the recombinant, catabolic plasmid pD10 in laboratory microcosms by natural mobilizing plasmids, recently isolated from epilithic bacteria by exogenous isolation in Pseudomonas putida, as opposed to their isolation in the strains in which they occur in situ. Initial experiments in simple, beaker microcosms were used to optimize conditions for selection of the donor, recipient and transconjugant populations. Studies in a recirculating stream microcosm showed that donor, $P$. putida KT2440(pD10, pQKH6), and recipient, P. putida UWC6, populations, although declining with time, were able to survive for three weeks and that colonization and survival was predominantly in the epilithon of the microcosm rather than in the liquid phase. Transconjugants UWC6(pD10, PQKH6) were also isolated from epilithon, showing that plasmid pD10 had been mobilized by plasmid pQKH6. The donor strain was able to survive at 100-fold greater numbers than the recipient, but transconjugants were not isolated after day 15. Separate inoculation of the donor and recipient strains into the microcosm showed that they were able to colonize other stones, where transconjugants then arose as a direct result of plasmid transfer within the epilithon. A catechol 2,3-dioxygenase gene, $\operatorname{tdn} C$, was used to facilitate identification of donors and transconjugants. Preliminary laboratory matings showed that PD10 transferred to indigenous epilithic strains identified as Pseudomonas fluorescens, P. chlororaphis and P. aureofaciens. These results suggest that in the absence of selection, mobilization of introduced recombinant genes encoded by pD10 occurs at easily detectable frequencies, even in an oligotrophic environment.

Keywords: plasmid mobilization, xenobiotic, recombinant, microcosm, Pseudomonas

\section{INTRODUCTION}

Gene cloning and the characterization of bacterial xenobiotic degradative genes have facilitated the construction of novel catabolic pathways, thereby extending the range of substrates which can be utilized by microorganisms (Weightman et al., 1984). Therefore, biodegradation offers a powerful means of eliminating toxic man-made organic pollutants from the environment (Chaudry \& Chapalamadugu, 1991). Hence there is a potential use for such recombinant xenobiotic-degrading plasmids in bioremediation. Soil microcosms are currently

Abbreviations: 3CB, 3-chlorobenzoate; $\mathrm{C230}$, catechol 2,3-dioxygenase; GEM, genetically engineered micro-organism; Suc, succinate. being extensively used to study the survival, stability and transfer of genetically engineered micro-organisms (GEMs) (Smit et al., 1993; Ramos et al., 1991) but relatively few studies have evaluated their survival and fate in freshwater environments (Awong et al., 1990).

We recently described the isolation of naturally-occurring epilithic plasmids which are capable of mobilizing pD10 (Hill et al., 1992; McClure et al., 1989), a recombinant nonconjugative catabolic plasmid which carries $t f d C, t f d D$ and $t f d E$ genes derived from plasmid pJP4 (Perkins $e t$ al., 1990 ), encoding the biodegradation of 3-chlorobenzoate (3CB), and provides a useful model chlorinated aromatic xenobiotic. Mobilization of GEMs has been shown to occur in activated sludge (McClure et al., 1990a) and surprisingly, also in drinking water (Sandt \& Herson, 
Table 1. Bacterial strains and plasmids used in this study

\begin{tabular}{|c|c|c|c|}
\hline $\begin{array}{l}\text { Strain or } \\
\text { plasmid }\end{array}$ & Phenotype & $\begin{array}{l}\text { Additions made for } \\
\text { selection }\end{array}$ & $\begin{array}{l}\text { Source or } \\
\text { reference }\end{array}$ \\
\hline \multicolumn{4}{|c|}{$\begin{array}{l}\text { Pseudomonas } \\
\text { putida strains }\end{array}$} \\
\hline $\mathrm{KT} 2440$ & Rif $^{s}$ & & $\begin{array}{l}\text { Bagdasarian et al. } \\
\text { (1981) }\end{array}$ \\
\hline UWC3 & $\operatorname{Rif}^{\mathrm{R}} \mathrm{Ilv}^{-}$ & $\operatorname{Rif}_{100}, \mathrm{Ilv}_{20}$ & Hill et al. (1992) \\
\hline UWC5 & $\mathrm{Rif}^{\mathrm{R}} \mathrm{Sm}^{\mathrm{R}} \operatorname{Trp}^{-}$ & $\operatorname{Rif}_{100}, \mathrm{Sm}_{1000}, \operatorname{Trp}_{25}$ & Hill et al. (1992) \\
\hline UWC6 & $\begin{array}{l}\text { Spontaneous } \mathrm{Nal}^{\mathrm{R}} \text { mutant } \\
\text { of UWC5 }\end{array}$ & $\begin{array}{l}\operatorname{Rif}_{100}, \mathrm{Sm}_{1000}, \mathrm{Nal}_{500}, \\
\operatorname{Trp}_{25}\end{array}$ & This study \\
\hline \multicolumn{4}{|l|}{ Plasmids } \\
\hline $\mathrm{pD} 10$ & $\mathrm{Km}^{\mathrm{R}} 3 \mathrm{CB}^{+} \mathrm{Tra}^{-} \mathrm{Mob}^{+}$ & $\mathrm{Km}_{50}, 3 \mathrm{CB}(5 \mathrm{mM})$ & $\begin{array}{l}\text { McClure et al. } \\
(1989)\end{array}$ \\
\hline pQKH6 & $\mathrm{Hg}^{\mathrm{R}} \mathrm{Tra}^{+}$ & $\mathrm{Hg}_{27}$ & Hill et al. (1992) \\
\hline PQKH9 & $\mathrm{Hg}^{\mathrm{R}} \mathrm{Tra}^{+}$ & $\mathrm{Hg}_{27}$ & Hill et al. (1992) \\
\hline PQM902 & $\mathrm{Hg}^{\mathrm{R}} \mathrm{Tra}^{+}, \mathrm{C} 23 \mathrm{O}^{+}$ & $\mathrm{Hg}_{27}$ & Bradley (1992) \\
\hline
\end{tabular}

Abbreviations: Rif, rifampicin; Sm, streptomycin; $\mathrm{Hg}$, mercuric chloride; 3CB, 3-chlorobenzoate; C23O, catechol-2,3-dioxygenase; Ilv, isoleucine, leucine, valine; Trp, tryptophan; Mob, mobilizable; Tra, conjugative. Values written in subscript are concentrations used in $\mu \mathrm{g} \mathrm{ml} l^{-1}$.

1991). The aim of this study was to investigate persistence and mobilization of $\mathrm{pD} 10$ by two epilithic mobilizing plasmids ( $\mathrm{pQKH} 6$ and $\mathrm{pQKH}$ ) in river epilithon using two types of laboratory microcosm.

\section{METHODS}

Bacterial strains and plasmids. The strains and plasmids used in this study are shown in Table 1. pmob indicates mobilizing plasmid (pQKH6, pQKH9 or pQM902). Plasmid pQM902 was constructed using the suicide vector Tn $5 \Delta:: m e r: t \operatorname{tdn} C$ transposon donor system (McClure et al., 1990b) to introduce the $t d n C$ gene (McClure \& Venables, 1987) linked to mercury resistance $\left(\mathrm{Hg}^{\mathrm{R}}\right)$ into plasmid pQKH6 (Bradley, 1992). All the Tn5-specified antibiotic resistance genes had been deleted or inactivated in this recombinant transposon. Hence plasmids pQM902 and pD10 could be distinguished from each other by use of the $\mathrm{Hg}^{\mathrm{R}}$ (mercuric chloride), $\mathrm{C}_{23} 3 \mathrm{O}^{+}$(catechol 2,3dioxygenase) and $\mathrm{Km}^{\mathrm{R}}$ (kanamycin) phenotypes respectively.

Detection of catechol 2,3-dioxygenase expression. Expression of the $t \operatorname{dn} C$ gene was detected by spraying selective plates with $1 \%(\mathrm{w} / \mathrm{v})$ catechol. A positive reaction was indicated by production of a yellow coloration due to the formation of 2 hydroxymuconic semialdehyde (Winstanley et al., 1989). Expression of the $\operatorname{tdn} C$ gene in plasmid pQM902 was tested and was not inhibited by the presence of $\mathrm{pD} 10$ in the same strain. However, $\mathrm{C} 23 \mathrm{O}$ expression was found to be inhibited by production of 3-chlorocatechol, a key metabolite formed during the degradation of 3CB (Reineke \& Knackmuss, 1980). C23O has previously been shown to be inactivated by 3-chlorocatechol (Bartels et al., 1984). Hence, colonies were first sprayed with catechol for $\mathrm{C} 23 \mathrm{O}$ expression and then subcultured on $3 \mathrm{CB}$ plates to confirm transconjugants.

Media for growth and maintenance of bacteria. The strains were maintained on either Luria-agar (L-agar) with the addition of appropriate antibiotics or on defined solid or liquid minimal media with carbon sources as described by Slater et al. (1979).
Succinate (Suc) $\left(1 \mathrm{~g} \mathrm{t}^{-1}\right)$ or $5 \mathrm{mM} \mathrm{3-chlorobenzoate} \mathrm{(3CB)} \mathrm{was}$ used as the carbon source. Media and supplements, including PSM (Pseudomonas selective medium), were as previously described (Hill et al., 1992). The following antibiotic additions were also used: streptomycin $(\mathrm{Sm}), 1000 \mu \mathrm{g} \mathrm{ml} \mathrm{m}^{-1}$ and nalidixic acid (Nal), $500 \mu \mathrm{g} \mathrm{ml}^{-1}$. R2A agar (Reasonner \& Geldriech, 1985) was used for the enumeration of heterotrophic bacteria in epilithic and planktonic samples. PCA broth (yeast extract, $2.5 \mathrm{~g} \mathrm{l}^{-1}$; pancreatic digest of casein, $5 \mathrm{~g} \mathrm{l}^{-1}$, Oxoid L43; glucose, $1 \mathrm{~g} \mathrm{t}^{-1}$ ) was used as the liquid phase in beaker microcosm experiments. One-tenth strength nutrient broth (NB/10; Oxoid CM3) was used for serial dilutions.

Beaker microcosm experiments. Initial mating experiments were carried out using $500 \mathrm{ml}$ plastic beakers with $100 \mathrm{ml}$ of liquid phase. Overnight cultures in L-broth of $P$. putida strains [donor KT2440(pD10, pQKH6 or pQKH9) (3 ml) and recipient UWC5 or UWC6 $(2 \mathrm{ml})$ ] strains were mixed and were immediately filtered onto a $0.2 \mu \mathrm{m}$ pore size membrane filter ( $25 \mathrm{~mm}$ diameter). The filters were then attached face-down, onto either sterile scrubbed or non-sterile stones as described by Bale et al. (1988b) and submerged in the beakers. The beakers were sealed in sterile stomacher bags (Seward Medical, Fisons Scientific Equipment) and incubated for $24 \mathrm{~h}$ at $20^{\circ} \mathrm{C}$. A series of mating experiments was carried out in the beaker microcosms using either sterile stones in PCA broth, sterile stones in River Taff water or stones with normal epilithon fresh from the River Taff in Taff water. Filters were removed and the attached biomass was resuspended in $10 \mathrm{ml} \mathrm{NB} / 10$. The stone surface previously in contact with the filter was also sampled by scrubbing with a sterile toothbrush in $10 \mathrm{ml} \mathrm{NB} / 10$ as described by Bale et al. (1988b). Donor, recipient and transconjugant viable counts from the filters, stones and liquid phase were enumerated.

Recirculating stream microcosm design and operation. The recirculating stream microcosm (LABCRAFT, South Glamorgan, UK) was built to the design of Vogel \& Labarbera (1978) and consisted of a perspex channel $(150 \times 21 \times 16 \mathrm{~cm})$ 
supported on a wooden frame as described by Day et al. (1992). The water was circulated by a $190 \mathrm{~W}$ brush-less electric motor (Parvalux, Bournemouth, UK) attached to the channel by the outflow pipe. Water was propelled through a ridged-PVC lagged pipe (diameter $10.16 \mathrm{~cm}$ ) to the stream inlet. The inlet and outlet pipes attached to the stream allowed recirculation of the water contained in the system. At both ends of the stream, turbulent flow was reduced using resin-impregnated honeycomb (DUFAYLITE, Dufaylite Developments, Cambridge, UK). The water temperature was controlled by a thermostat linked to heating and cooling coils placed near the stream outlet pipe and was monitored by a temperature probe near the stream inflow. The temperature of the microcosm was maintained at $20^{\circ} \mathrm{C}$ or $15^{\circ} \mathrm{C}$. Stones with epilithon were collected from a shallow area in the lower reaches of the River Taff (Ordnance Survey Grid Reference ST 164783). Approximately 50 freshly collected stones were placed in the microcosm. This was subsequently filled to a total volume of $50 \mathrm{l}$ with freshly collected river water. The flow rate of the circulating water was maintained at a constant velocity of $0.5 \mathrm{~m} \mathrm{~s}^{-1}$ throughout. The filled microcosm was disinfected between experiments by recirculating Chempro SDP steriliser $\left(5 \mathrm{~g} \mathrm{l}^{-1}\right.$, Chempro DDD) for $24 \mathrm{~h}$ followed by extensive rinsing with water. The effectiveness of this procedure was evaluated prior to each subsequent experiment by an inability to isolate the donor and recipient strains from the microcosm on solid selective media. The microcosm was equilibrated for one week before each experiment.

\section{Mating experiments in the recirculating stream microcosm.} P. putida donor strain, KT2440(pD10, pQKH6 or pQM902), and recipient strain, UWC6, were mixed on membrane filters as described above. Two sterile control filters attached to sterile stones were also placed in the microcosm at the beginning of each microcosm experiment. These stones were removed after $24 \mathrm{~h}$ and viable counts of donors, recipients and transconjugants on the filters and on the stone surface previously covered by the filter were made as described above. At the same time counts were also made of two $10 \mathrm{ml}$ liquid phase samples.

After removal of the filters, the microcosm was sampled every 2-3 d by removing two stones for epilithic samples and two $10 \mathrm{ml}$ planktonic samples. These samples were taken randomly. Epilithic suspensions were prepared by scrubbing the whole stone as described above and total viable heterotroph, donor, recipient and transconjugant populations were determined. The remaining epilithic samples were frozen at $-70{ }^{\circ} \mathrm{C}$ for carbohydrate analysis.

P. putida strain KT2440(pD10, pQKH6) was used as the donor in the first microcosm experiment at $20^{\circ} \mathrm{C}$, whereas KT2440(pD10, pQM902) was used in subsequent experiments (at 15 and $20^{\circ} \mathrm{C}$, respectively). The recipient was $P$. putida strain UWC6. Viable counts on $\mathrm{Suc}+\mathrm{HgCl}_{2}$ were made for enumeration of all donor strains and on PSM with appropriate antibiotic additions for enumeration of the recipient strains UWC5 and UWC6 and transconjugants. For transconjugants counts, $5 \mathrm{ml}$ epilithic suspension was concentrated and the pellet resuspended in $1 \mathrm{ml} \mathrm{NB} / 10$ before spread-plating onto the very dry surface of the relevant selective plate. Transconjugants were routinely confirmed phenotypically and by plasmid identification using a modified version of Kado \& Liu's (1981) lysis and gel electrophoresis protocol as described by Rochelle et al. (1986). All colonies tested were confirmed as transconjugants. Total viable heterotroph populations were enumerated on R2A agar.

Control experiments. Donor and recipient strains were routinely plated onto all selective media as controls for selection.
Initial transfers in the beaker microcosms were carried out with recipient and transconjugant selection on PSM $+\mathrm{Rif}+\mathrm{Sm}$ and $\mathrm{PSM}+\mathrm{Rif}+\mathrm{Sm}+\mathrm{Km}$, respectively. However, control plates of donor and recipient strains filtered and plated out immediately showed that a small number of transconjugants were arising as a result of mating occurring on the plate surface (Table 2a). Additions of $\mathrm{Nal}$ as a selective agent in conjunction with use of a $\mathrm{Nal}^{\mathrm{R}}$ recipient strain prevented this (Table $2 \mathrm{~b}$ ).

Mobilization of plasmid pD10 to indigenous epilithic bacteria. A $1 \mathrm{ml}$ overnight culture of donor strain UWC6(pD10, pQKH6) was mixed with $1 \mathrm{ml}$ fresh epilithic suspension, MNS (Hill et al., 1992), then poured onto the surface of a very dry PCA plate, and incubated overnight at $30^{\circ} \mathrm{C}$. The overnight growth was harvested into $10 \mathrm{ml} \mathrm{NB} / 10$ and dilutions were plated onto $\mathrm{Suc}+\mathrm{Km}+\mathrm{Hg}, \mathrm{Suc}+\mathrm{Km}, \quad 3 \mathrm{CB}+\mathrm{Km}$ and $3 \mathrm{CB}+\mathrm{Km}+\mathrm{Hg}$ selective media. Putative transconjugants thus selected were characterized both phenotypically and genotypically as described above and were identified to species level using the API 20NE identification kit (API-Biomerieux UK). Expression of plasmid pD10 3CB biodegradative genes in such transconjugants was confirmed by testing their ability to release $\mathrm{Cl}^{-}$from 3CB in liquid culture (Slater et al., 1979).

Carbohydrate assay. The carbohydrate content of the epilithon and bacterial heterotrophs was monitored throughout each experiment to determine whether the aquatic biofilm was maintained in the microcosm. The assay used was the phenol/ sulphuric acid method of Gerchakov \& Hatcher (1972).

Statistics. Statistical analysis of the data was as described by Hill et al. (1992).

\section{RESULTS Beaker microcosm experiments}

Transconjugants containing $\mathrm{pD} 10$ were detected in all mating experiments in the beaker microcosms (Table 2) and were detected in all three habitats sampled (on the filter, the stone surface and in the liquid phase of the system). Mobilization of pD10 was observed at frequencies (for all matings) well above those detected in control experiments with selection made on minimal media $\left(10^{-6}-10^{-7}\right)$.

Mobilization frequencies from KT2440(pD10, pmob) to UWC5 ranged between $10^{-3}$ and $10^{-5}$ per recipient ('Table $2 a)$. To prevent mating from occurring on the plate surface after spread-plating (Table 2a), a Nal ${ }^{\mathbf{R}}$ UWC5 derivative (UWC6) was used as the recipient strain with selection on $\mathrm{Nal}$ (Table $2 \mathrm{~b}$ ). Nalidixic acid inhibits DNA gyrase activity, which is necessary for successful conjugation (Sugino et al., 1977). No significant difference to the transfer frequencies was observed with this recipient strain $(P=0.367)$ by comparison with strain UWC5. However, plasmid pQKH6 gave significantly higher mobilization frequencies of pD10 to UWC6 than did pQKH9 $(P=0.039)$. Two-way analysis of variance showed that substitution of Taff water for PCA broth in the liquid phase produced a significant drop in mobilizing frequency $(P=0.003)$, although the actual frequencies measured remained high $\left(10^{-3}-10^{-4}\right.$; Table $\left.2 \mathrm{~b}\right)$. No significant difference was found between the habitats sampled $(P=0 \cdot 223)$, suggesting that the mobilization 
Table 2. Apparent mean mobilization frequencies (per recipient) for pD10 in beaker microcosms at $20^{\circ} \mathrm{C}$

The results are means of two determinations.

\begin{tabular}{|c|c|c|c|c|}
\hline \multirow{2}{*}{$\begin{array}{l}\text { Microcosm } \\
\text { conditions }\end{array}$} & \multirow{2}{*}{$\begin{array}{l}\text { Mobilizing } \\
\text { plasmid }\end{array}$} & \multicolumn{3}{|c|}{ Sample } \\
\hline & & Filter & Stones & $\begin{array}{l}\text { Liquid } \\
\text { phase }\end{array}$ \\
\hline \multicolumn{5}{|c|}{$\begin{array}{l}\text { (a) } \mathrm{KT} 2440(\mathrm{pD} 10, \mathrm{pmob}) \times \mathrm{UWC} 5: \\
\text { selection on PSM }+\mathrm{Rif}_{100}+\mathrm{Sm}_{1000}+\mathrm{Km}_{50}\end{array}$} \\
\hline $\begin{array}{l}\text { Sterile stone/ } \\
\text { PCA broth }\end{array}$ & $\begin{array}{l}\text { pQKH6 } \\
\text { pQKH9 }\end{array}$ & $\begin{array}{l}6 \cdot 0 \times 10^{-4} \\
2 \cdot 8 \times 10^{-3}\end{array}$ & $\begin{array}{l}2.6 \times 10^{-4} \\
2 \cdot 9 \times 10^{-3}\end{array}$ & $\begin{array}{l}9 \cdot 2 \times 10^{-5} \\
1 \cdot 9 \times 10^{-3}\end{array}$ \\
\hline $\begin{array}{l}\text { Sterile stone/ } \\
\text { Taff water }\end{array}$ & $\begin{array}{l}\mathrm{pQKH6} \\
\mathrm{pQKH} 9\end{array}$ & $\begin{array}{l}4 \cdot 1 \times 10^{-4} \\
8 \cdot 3 \times 10^{-4}\end{array}$ & $\begin{array}{l}4.7 \times 10^{-4} \\
6.2 \times 10^{-4}\end{array}$ & $\begin{array}{l}6.8 \times 10^{-4} \\
2 \cdot 2 \times 10^{-3}\end{array}$ \\
\hline $\begin{array}{l}\text { Epilithon-covered } \\
\text { stone/Taff water }\end{array}$ & $\begin{array}{l}\text { pQKH6 } \\
\text { pQKH9 }\end{array}$ & $\begin{array}{l}6.6 \times 10^{-4} \\
8 \cdot 3 \times 10^{-4}\end{array}$ & $\begin{array}{l}4 \cdot 2 \times 10^{-4} \\
5.4 \times 10^{-4}\end{array}$ & $\begin{array}{l}9 \cdot 2 \times 10^{-5} \\
1.5 \times 10^{-3}\end{array}$ \\
\hline $\begin{array}{l}\text { Control } \\
\text { plates* }\end{array}$ & $\begin{array}{l}\text { pQKH6 } \\
\text { pQKH9 }\end{array}$ & $\begin{array}{l}3.3 \times 10^{-7} \\
2.6 \times 10^{-7}\end{array}$ & & \\
\hline \multicolumn{5}{|c|}{$\begin{array}{l}\text { (b) KT2440(pD10, pmob) } \times \text { UWC6: } \\
\text { selection on PSM }+ \text { Rif }_{100}+\mathrm{Nal}_{500}+\mathrm{Km}_{50}\end{array}$} \\
\hline $\begin{array}{l}\text { Sterile stone/ } \\
\text { PCA broth }\end{array}$ & $\begin{array}{l}\text { pQKH6 } \\
\text { pQKH9 }\end{array}$ & $\begin{array}{l}2 \cdot 7 \times 10^{-3} \\
1 \cdot 7 \times 10^{-3}\end{array}$ & $\begin{array}{l}2 \cdot 9 \times 10^{-3} \\
1 \cdot 0 \times 10^{-3}\end{array}$ & $\begin{array}{l}4 \cdot 7 \times 10^{-3} \\
2 \cdot 1 \times 10^{-3}\end{array}$ \\
\hline $\begin{array}{l}\text { Sterile stone/ } \\
\text { Taff water }\end{array}$ & $\begin{array}{l}\text { pQKH6 } \\
\text { pQKH9 }\end{array}$ & $\begin{array}{l}1.0 \times 10^{-3} \\
4.7 \times 10^{-4}\end{array}$ & $\begin{array}{l}9 \cdot 2 \times 10^{-4} \\
3 \cdot 4 \times 10^{-4}\end{array}$ & $\begin{array}{l}6 \cdot 7 \times 10^{-4} \\
2 \cdot 9 \times 10^{-4}\end{array}$ \\
\hline $\begin{array}{l}\text { Epilithon covered } \\
\text { stone/Taff water }\end{array}$ & $\begin{array}{l}\text { pQKH6 } \\
\text { pQKH9 }\end{array}$ & $\begin{array}{l}1.5 \times 10^{-3} \\
8.3 \times 10^{-4}\end{array}$ & $\begin{array}{l}7 \cdot 2 \times 10^{-4} \\
3.6 \times 10^{-4}\end{array}$ & $\begin{array}{l}2 \cdot 1 \times 10^{-4} \\
3 \cdot 1 \times 10^{-4}\end{array}$ \\
\hline $\begin{array}{l}\text { Control } \\
\text { plates* }\end{array}$ & $\begin{array}{l}\text { pQKH6 } \\
\text { pQKH9 }\end{array}$ & $\begin{array}{l}\text { ND } \\
\text { ND }\end{array}$ & & \\
\hline
\end{tabular}

Abbreviations: PSM, Pseudomonas selective medium; pmob, mobilizing plasmid; ND, not detected. For other abbreviations see footnote and text of Table 1.

* Mean transfer frequency of two determinations where donor and recipient strains were mixed and plated out immediately; minimum significant difference $=1.27 \log _{10}$ units.

frequencies obtained from the filter, stone and liquid phase in the beaker microcosms were essentially similar.

\section{Recirculating stream microcosm experiments}

Three separate microcosm experiments were carried out to investigate mobilization of plasmid pD10 in riverine epilithon. In the first experiment, four filters carrying a mixture of P. putida KT2440(pD10, pQKH6) donor and UWC6 recipient strains and two sterile control filters, all attached to separate sterile stones, were placed in the microcosm at $20^{\circ} \mathrm{C}$ for $24 \mathrm{~h}$. A mean transfer frequency of $1.6 \times 10^{-3}$ per recipient was obtained for mobilization of $\mathrm{pD} 10$ on the filters in the microcosm, and of $1.6 \times 10^{-3}$ per recipient on the stone surface. These frequencies were about one order of magnitude lower than the mean frequency of mobilization of pD10 in control standard laboratory plate matings $\left(1.7 \times 10^{-2}\right.$ per recipient). Following removal of the filters and the stones to which they were attached, the microcosm was regularly sampled to determine the donor, recipient and transconjugant numbers remaining in the epilithon and liquid phase (Fig. 1).

A second identical experiment was carried out using three inoculated filters, but instead, KT2440(pD10, pQM902) was used as the donor strain and the microcosm was maintained at $15{ }^{\circ} \mathrm{C}$. Plasmid pQM902

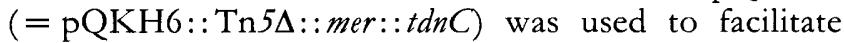
selection and confirmation of transconjugants. Mean mobilization frequencies of pD10 obtained on the filters, the stone surface and in control laboratory plate matings $\left(3.2 \times 10^{-3}, 2 \cdot 0 \times 10^{-2}\right.$ and $5 \cdot 3 \times 10^{-2}$ respectively) compared well with those determined in the first experiment. Fig. 2 shows the numbers of donors, recipients and transconjugants remaining in the epilithon and the liquid phase of the microcosm after removal of the filters in this second experiment.

In a third microcosm experiment (again maintained at $20^{\circ} \mathrm{C}$ ), the donor and recipient cultures were not mixed prior to inoculation. Two filters with only donor KT2440(pD10, pQM902) and two separate filters with 


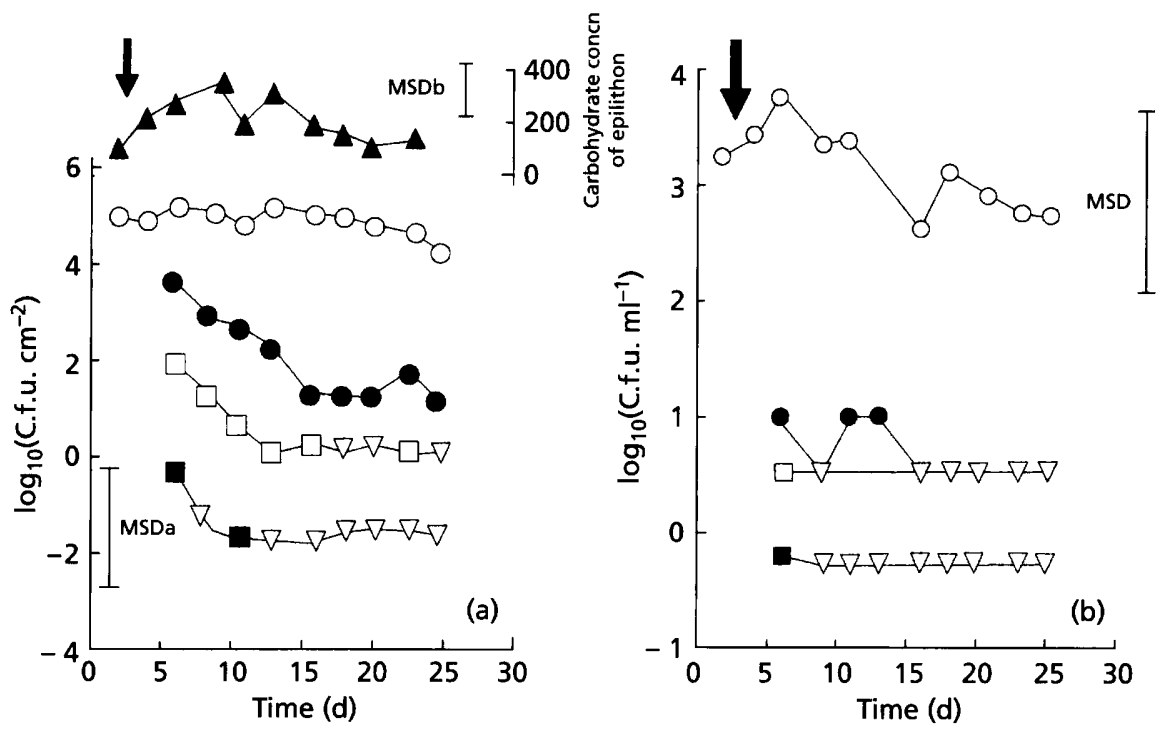

Fig. 1. Survival of $P$. putida strains and transfer of pD10 in a recirculating stream microcosm using pQKH6 at $20^{\circ} \mathrm{C}$; donor and recipient inoculated on the same filter. Change in (a) c.f.u. per $\mathrm{cm}^{2}$ stone area and carbohydrate concentration as $\mu \mathrm{g}$ glucose equivalents $\mathrm{ml}^{-1}$ in epilithon and (b) c.f.u. $\mathrm{ml}^{-1}$ in the liquid phase. $O$, Total aerobic heterotrophs; 0 , donors [KT2440(pD10, pQKH6)]; $\square$, recipients (UWC6); $\mathbf{a}$, transconjugants; $\boldsymbol{\Delta}$, and mean carbohydrate concentration. $\nabla$ indicates counts below the limit of detection; arrow indicates inoculation time when filters with donor and recipient strains were added to the microcosm. MSD and MSDa, minimum significant difference for bacterial counts; MSDb, minimum significant difference for carbohydrate concentrations.

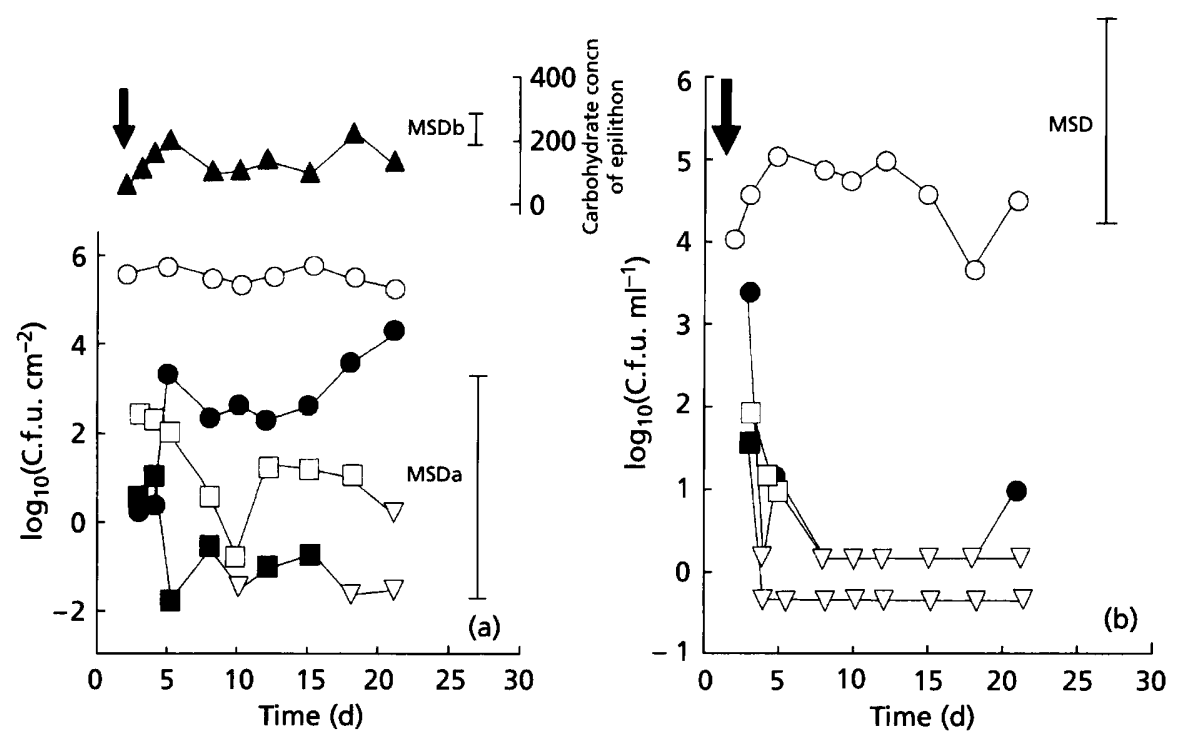

Fig. 2. Survival of $P$. putida strains and transfer of pD10 in a recirculating stream microcosm using pQM902 at $15^{\circ} \mathrm{C}$; donor and recipient inoculated on the same filter. Change in (a) c.f.u. per $\mathrm{cm}^{2}$ stone area and carbohydrate concentration as $\mu \mathrm{g}$ glucose equivalents $\mathrm{ml}^{-1}$ in epilithon and (b) c.f.u. $\mathrm{ml}^{-1}$ in the liquid phase. Symbols are as for Fig. 1 except that the donor (O) was KT2440(pD10, pQM902).

only recipient UWC6 (each with $3 \mathrm{ml}$ of overnight culture) were attached to individual stones before being placed in the microcosm for $24 \mathrm{~h}$. The microcosm was sampled for a week prior to inoculation to ensure that no false positive donor, recipient or transconjugant counts were obtained. Bacterial loss from the inoculated filters allowed these strains to mix in the epilithon of uninoculated stones and the liquid phase of the microcosm, 


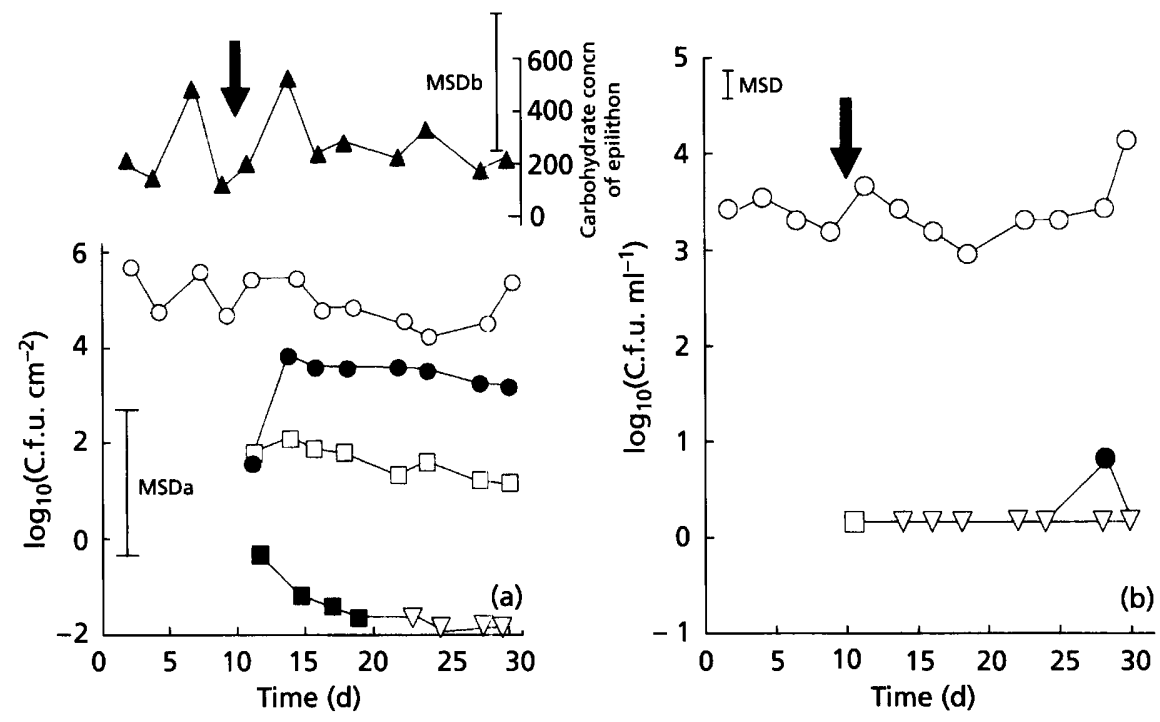

Fig. 3. Survival of $P$. putida strains and transfer of pD10 in a recirculating stream microcosm using $\mathrm{pQM} M 02$ at $20^{\circ} \mathrm{C}$; donor and recipient inoculated onto different filters and stones. Change in (a) c.f.u. per $\mathrm{cm}^{2}$ stone area and carbohydrate concentration as $\mu \mathrm{g}$ glucose equivalents $\mathrm{ml}^{-1}$ in epilithon and (b) c.f.u. $\mathrm{ml}^{-1}$ in the liquid phase. Symbols are as for Fig. 1 except that the donor (O) was KT2440(pD10, pQM902).

where they were monitored following removal of the filters and the stones to which they were attached (Fig. 3). Therefore, any contact between the donor and recipient strains occurred after placement of the filters in the microcosm.

In all three experiments, donor and recipient populations were detected in the epilithon of most stones and in the liquid phase of the microcosm, showing that a $24 \mathrm{~h}$ period was sufficient for efficient introduction and spread of these strains throughout the microcosm. Figs 1(a), 2(a) and 3(a) show that, generally, the donor and recipient populations declined slightly with time over the three week monitoring period. The donor strain KT2440(pD10, pmob) survived in high numbers in the epilithon but viable counts were slightly higher at $20^{\circ} \mathrm{C}$ (Fig. 3a) than at $15^{\circ} \mathrm{C}$ (Fig. 2a). The recipient strain UWC6 was also maintained, although these counts were 100 -fold lower than those for the donor strain, and fell close to (and, in two samples, below) the limits of detection for this strain (Figs 1-3). Neither strain survived well in the liquid phase of the microcosm.

Transconjugants were detected at low but significant frequencies in all microcosm experiments and were found to occur predominantly in the epilithon (Figs 1-3). Taken together, these results clearly show that the mobilization of plasmid $\mathrm{pD} 10$ had occurred in the microcosm. Low transconjugant counts may be attributed to a low transfer frequency, or equally can be correlated to an inability to consistently detect the recipient strain during the same period. Plasmid preparations of putative transconjugants all showed the presence of pD10 and pQKH6 or pQM902, and no structural rearrangements were observed. In all three microcosm experiments, control plates showed that no mating occurred on the surface of the plates after spread-plating. Transconjugants were enumerated on the sterile control filters placed in the microcosm for $24 \mathrm{~h}$ and in all experiments they were found to be present on the filters and the stone surface at just detectable levels.

The heterotroph population in the epilithon and the liquid phase remained fairly constant for each experiment, with no significant difference in the counts obtained within experiments (Figs 1,2 and 3). However, the carbohydrate concentration of the epilithic suspension fluctuated by more than the minimum significant difference in each experiment. The carbohydrate analysis is a measure of epilithon concentration and this result suggests that the depth of the epilithon in the microcosm varied during the experiments.

\section{Mobilization of pD10 to indigenous epilithic bacteria}

Preliminary laboratory plate matings between auxotrophic donor P. putida strain UWC6(pD10, pQKH6) and suspensions of epilithon resulted in the selection of epilithic transconjugants containing $\mathrm{pD} 10$. Eleven putative transconjugants isolated on $\mathrm{Suc}+\mathrm{Km}+\mathrm{Hg}$ were selected for more detailed characterization. Plasmids pD10 and pQKH6 were detected in all these strains, indirectly by their resistance markers and directly by plasmid isolation. Nine of them were able almost completely to dechlorinate $3 \mathrm{CB}$ in liquid culture, indicating that the $3 \mathrm{CB}$ degradation genes encoded by plasmid $\mathrm{PD} 10$ were co-transferred and expressed in these strains. Although two of the transconjugants could not be identified using the API 20NE kit, the others were as follows: Pseudomonas fluorescens, Pseudomonas chlororaphis, Pseudomonas aureofaciens and a Bordetella-like species. This method of species identification is not always reliable. However, these results show that although such trans- 
conjugants had not been selected in the microcosm, plasmid $\mathrm{pD} 10$ could be mobilized to a range of different epilithic species.

\section{DISCUSSION}

Experiments described in this paper have confirmed that the recirculating stream microcosm is a good model for the study of gene transfer systems in river epilithon. It has already been shown that the microcosm is able to simulate the environmental factors which affect conjugation. Fry $e t$ al. (1991) showed that the transfer frequencies of plasmid pQM1 between $P$. aeruginosa donor PAO2002 and recipient PU21 did not differ significantly from those obtained in situ in the River Taff (Day et al., 1992; Bale et al., 1988a). The present study extends these findings to an investigation of recombinant gene transfer by plasmid mobilization.

Results from matings in simple beaker microcosms were extremely useful in that they facilitated the choice of mobilizing plasmids (pQKH6 and its derivative pQM902) for use in subsequent experiments and simplified extrapolation of this mating system to the recirculating stream microcosm. The frequencies of mobilization observed here suggested that frequencies obtained in the stream microcosm would be sufficiently high to enable detection. The use of the genetic marker $t d n C$, carried by the mobilizing plasmid pQM902, made rapid and easy identification of transconjugants possible, although these were always confirmed by establishing the physical presence of plasmid DNA. The use of this marker also verified that the selective media used worked well.

In all three microcosm experiments a similar decline in donor and recipient population profiles was observed following introduction into the recirculating stream microcosm, whether together or separately. This initial decline in numbers, followed by a stabilizing of the donor and recipient populations, is consistent with declines in populations of Aeromonas salmonicida (Morgan et al., 1993) and Pseudomonas spp. (Scheuerman et al., 1988) observed in unsterile lake water. It is generally recognized that survival and maintenance of bacteria introduced exogenously into aquatic environments containing an indigenous microflora may be affected by a number of factors (Liang et al., 1982). These include: starvation (Sinclair \& Alexander, 1984); predation (Scheuerman, 1988); competition with the indigenous microflora (McClure et al., 1989); the presence of antimicrobial toxins (Klein \& Alexander, 1986); and temperature (Day et al., 1992). Within the narrow range investigated in this study, temperature had only a small effect on survival of the introduced strains. However, these microcosm experiments did suggest that the survival and mobilization of pD10 by pQKH6 may be better at $20^{\circ} \mathrm{C}$ than at $15^{\circ} \mathrm{C}$, since the donor strain was maintained at higher numbers at the higher temperature. A change in temperature of $5^{\circ} \mathrm{C}$ is well within the normal annual fluctuations of the River Taff and reflects the robustness of $P$. putida, which is able to grow and proliferate over a very wide temperature range (about $4^{\circ} \mathrm{C}$ to $40^{\circ} \mathrm{C}$ ).
Two other general observations were made regarding survival of bacteria into the microcosm. First, the prototrophic donor strain always survived better than the auxotrophic recipient. Since these strains are isogenic, except in respect of plasmid content and one or two selectable markers, it seems likely that nutritional status was the main contributing factor accounting for this observation. Second, survival of both strains was far better in the epilithon than in the liquid phase of the microcosm. Indeed, the donor and recipient populations of the liquid phase were close to and often below the limits of detection and few transconjugants (seven in total) were detected. This is consistent with the study of Geesey et al. (1977), who also found that the epilithon favours colonization, since the liquid phase is low in readily available nutrients. Possible factors reducing conjugation and plasmid mobilization in the liquid phase are poor cell-to-cell contact and the expression of certain pilus types such as rigid IncP1 pili (Bradley, 1980) for which transfer proceeds at far higher frequencies on solid media than in liquid (Bradley et al., 1983).

In the third experiment (Fig. 3), where the donor and recipient populations were spatially separated in the microcosm, transconjugants arose as a direct result of the dispersal to and colonization of new stones by both strains where plasmid transfer subsequently occurred. The epilithic biofilm is a dynamic habitat which is continuously being renewed, thereby causing the rapid colonization of uncolonized stones. The microcosm experiment further indicates that colonization of an existing epilithon by exogenously introduced strains can also occur rapidly, to the extent that genetic interactions may be detected. This experiment mimics conditions likely to be encountered in the event of the accidental release of a GEM into the riverine environment. For example, the application of GEMs in waste-treatment is likely to result in their dispersal in the water-table to rivers and streams. Even in the absence of selection for plasmid encoded traits, recombinant gene transfer may still occur at high frequencies.

Mobilization of GEMs to the indigenous soil microflora has been shown to occur in situ to P. fluorescens (Henschke \& Schmidt, 1990), and Genthner et al. (1988) also demonstrated the ability of aquatic bacteria to act as recipients of the broad-host-range plasmids R68 and R1162. However, assessment of transfer to the indigenous population requires the use of a suitable donor counterselection method, such as the use of donor-specific bacteriophages (Smit et al., 1991). In initial laboratory mating experiments, transfer of $\mathrm{pD} 10$ to the indigenous epilithic population was successful and was primarily to Pseudomonas spp., indicating that these strains are those most likely to act as natural recipients in epilithon in situ.

The results of this study validate the use of this microcosm to study gene transfer in an aquatic environment. Unlike previous studies where plasmid mobilization has been shown to occur in nutrient-rich environments such as wastewater (McPherson \& Gealt, 1986) and activated sludge (McClure et al., 1989), we have shown mobilization 
of a GEM under conditions of low nutrient availability. Given that a variety of mobilizing plasmids are naturally present in the aquatic environment which can transfer at high frequency into Pseudomonas spp. (McClure et ai., 1989; Hill et al., 1992), it would seem inevitable that any recombinant catabolic genes of the type used in this study (and probably other IncQ plasmids) would rapidly spread when released to the environment. Even the use of sophisticated suicide containment vectors (Contreras $e t$ al., 1991), which attempt to prevent recombinant gene transfer occurring, cannot be completely effective when the potential for mobilization into and out of exogenously introduced bacteria is so high.

\section{ACKNOWLEDGEMENTS}

This work was supported by a research studentship (K.E.H.) from the Natural Environment Research Council, for which we are grateful. We also thank David Bradley for plasmid pQM902.

\section{REFERENCES}

Awong, J., Bitton, G. \& Chaudry, G. R. (1990). Microcosm for assessing survival of genetically engineered microorganisms in aquatic environments. Appl Environ Microbiol 56, 977-983.

Bagdasarian, M., Lurz, R., Rückert, B., Franklin, F. C. H., Bagdasarian, M. M., Frey, J. \& Timmis, K. N. (1981). Specific purpose plasmid cloning vectors. II. Broad-host range, high copy number, RSF1010-derived vectors, and a host-vector system for gene cloning in Pseudomonas. Gene 16, 237-247.

Bale, M. J., Fry, J. C. \& Day, M. J. (1988a). Transfer and occurrence of large mercury resistance plasmids in river epilithon. Appl Environ Microbiol 54, 972-978.

Bale, M. J., Fry, J. C. \& Day, M. J. (1988b). Novel method for studying plasmid transfer in undisturbed river epilithon. $A p p l$ Environ Microbiol 54, 2756-2758.

Bartels, I., Knackmuss, H. J. \& Reineke, W. (1984). Suicide inactivation of catechol 2,3-dioxygenase from Pseudomonas putida mt-2 by 3-halocatechols. Appl Environ Microbiol 47, 500-505.

Bradley, D. E. (1980). Determination of pili by conjugative bacterial drug resistance plasmids of incompatibility groups $\mathrm{B}, \mathrm{C}, \mathrm{H}, \mathrm{J}, \mathrm{K}$, M, V and X. J Bacteriol 141, 828-837.

Bradley, D. E. (1983). Specification of the conjugative pili and surface mating systems of Pseudomonas plasmids. J Gen Microbiol 129, 2545-2556.

Bradley, D. J. (1992). Gene transfer in the epilithon of river stones. $\mathrm{PhD}$ thesis, University of Wales, Cardiff, UK.

Chaudry, G. R. \& Chapalamadugu, S. (1991). Biodegradation of halogenated organic compounds. Microbiol Rev 55, 59-79.

Contreras, A., Molin, S. \& Ramos, J. L. (1991). Conditional-suicide containment system for bacteria which mineralize aromatics. Appl Emiron Microbiol 57, 1504-1508.

Day, M. J., Fry, J. C. \& Diaper, J. (1992). Effect of host cell physiology on plasmid transfer in river epilithon. In Gene Transfers and Environment, pp. 35-50. Edited by M. J. Gauthier. Berlin: Springer-Verlag.

Fry, J. C., Day, M. J. \& Cousland, B. (1991). Transfer, survival and spread of genetically manipulated organisms (GMOs) in river sediments, soil and agricultural environments. In Biotechnology $R \& D$ in the EC, vol. II, Detailed Final Report of BAP Contractors. Edited by A. Vassarotti \& E. Magnien. Amsterdam: Elsevier.

Geesey, G. G., Richardson, W. T., Yeoman, H. G., Irvin, R. T. \&
Costerton, J. W. (1977). Microscopic examination of natural sessile bacterial populations from an alpine stream. Can J Microbiol 23, 1733- 1736.

Genthner, F., Chatterjee, J. P., Barkay, T. \& Bourquin, A. W. (1988). Capacity of aquatic bacteria to act as recipients of plasmid DNA. Appl Environ Microbiol 54, 115-117.

Gerchakov, S. M. \& Hatcher, P. G. (1972). Improved technique for analysis of carbohydrates in sediments. Limnol Oceanog 17, 938-943.

Henschke, R. B. \& Schmidt, F. R. J. (1990). Plasmid mobilization from a genetically engineered bacteria to members of the indigenous soil microflora in situ. Curr Microbial 20, 105-110.

Hill, K. E., Weightman, A. J. \& Fry, J. C. (1992). Isolation and screening of plasmids from epilithic bacteria which mobilize recombinant plasmid pD10. Appl Environ Microbiol 58, 1292-1300.

Kado, C. I. \& Liu, S. T. (1981). Rapid procedure for detection and isolation of large and small plasmids. J Bacteriol 145, 1365-1373.

Klein, T. M. \& Alexander, M. (1986). Bacterial inhibitors in lake water. Appl Environ Microbiol 52, 114-118.

Liang, L. N., Sinclair, J. L., Mallory, L. \& Alexander, M. (1982). Fate in model ecosystems of microbial species of potential use in genetic engineering. Appl Environ Microbiol 44, 708-714.

McClure, N. C., Weightman, A. J. \& Fry, J. C. (1989). Survival of Pseudomonas putida UWC1 containing cloned catabolic genes in a model activated-sludge system. Appl Environ Microbiol 55, 2627-2634.

McClure, N. C., Fry, J. C. \& Weightman, A. J. (1990a). Gene transfer in activated sludge. In Bacterial Genetics in Natural Environments, pp. 111-129. Edited by J. C. Fry \& M. J. Day. London: Chapman \& Hall.

McClure, N. C., Saint, C. P., Fry, J. C. \& Weightman, A. J. (1990b). The construction of broad-host range genetic markers and their use in monitoring the release of catabolic GEMs to aquatic environments. In 5th European Congress on Biotechnology, Proceedings vol. 1, pp. 169-172. Edited by C. Christiansen, L. Munck \& J. Villadsen. Copenhagen: Munksgaard.

McClure, N. C. \& Venables, W. A. (1987). pTDN1, a catabolic plasmid involved in aromatic amine catabolism in Pseudomonas putida mt-2. J Gen Microbiol 133, 2073-2077.

McPherson, P. \& Gealt, M. A. (1986). Isolation of indigenous wastewater bacterial strains capable of mobilizing plasmid pBR325. Appl Environ Microbiol 51, 904-909.

Morgan, J. A. W., Rhodes, G. \& Pickup, R. W. (1993). Survival of non-culturable Aeromonas salmonicida in lake water. Appl Environ Microbiol 59, 874-880.

Perkins, E. J., Gordon, M. P., Caceres, O. \& Lurquin, P. F. (1990). Organisation and sequence analysis of the 2,4-dichlorophenol hydrolase and dichlorocatechol oxidative operons of plasmid pJP4. J Bacteriol 172, 2351-2359.

Ramos, J. L., Duque, E. \& Ramos-Gonzalez, M. (1991). Survival in soils of an herbicide-resistant Pseudomonas putida strain bearing a recombinant TOL plasmid. Appl Environ Microbiol 57, 260-266.

Reasonner, D. J. \& Geldriech, E. E. (1985). A new medium for the enumeration and subculture of bacteria from potable water. $A p p l$ Environ Microbiol 49, 1-7.

Reineke, W. \& Knackmuss, H. J. (1980). Hybrid pathway for chlorobenzoate metabolism in Pseudomonas sp. B13 derivatives. $J$ Bacteriol 142, 467-473.

Rochelle, P. A., Fry, J. C. \& Day, M. J. (1986). An accurate method for estimating sizes of small and large plasmids and DNA fragments by gel electrophoresis. $J$ Gen Microbiol 132, 53-59.

Sandt, C. H. \& Herson, D. S. (1991). Mobilization of the genetically 
engineered plasmid pHSV106 from Escherichia coli HB101(pHSV106) to Enterobacter cloacae in drinking water. Appl Environ Microbiol 57, 194-200.

Scheuerman, P. R., Schmidt, J. P. \& Alexander, M. (1988). Factors affecting the survival and growth of bacteria introduced into lake water. Arch Microbiol 150, 320-325.

Sinclair, J. L. \& Alexander, M. (1984). Role of resistance to starvation in bacterial survival in sewage and lake water. Appl Environ Microbiol 48, 410-415.

Slater, J. H., Lovatt, D., Weightman, A. J., Senior, E. \& Bull, A. T. (1979). The growth of Pseudomonas putida on chlorinated aliphatic acids and its dehalogenase activity. J Gen Microbiol 114, 125-136.

Smit, E., Van Elsas, J. D., Van Veen, J. A. \& de Vos, W. M. (1991). Detection of plasmid transfer from Pseudomonas fuorescens to indigenous bacteria in soil by using bacteriophage $\phi \mathrm{R} 2 \mathrm{f}$ for donor counterselection. Appl Environ Microbiol 57, 3482-3488.

Smit, E., Venne, D. \& Van Elsas, J. D. (1993). Mobilization of a recombinant IncQ plasmid between bacteria on agar and in soil via cotransfer or retrotransfer. Appl Environ Microbiol 59, 2257-2263.
Sugino, A., Peebles, C. L., Kreuzer, K. N. \& Cozzarelli, N. R. (1977). Mechanism of action of nalidixic acid: purification of Escherichia coli nal $A$ gene product and its relationship to DNA gyrase and a novel nicking-closing enzyme. Proc Natl Acad Sci USA 74, 4767-4771.

Vogel, S. \& Labarbera, M. (1978). Simple flow tanks for research and teaching. Bioscience 28, 638-643.

Weightman, A. J., Don, R. H., Lehrbach, P. R. \& Timmis, K. N. (1984). The identification and cloning of genes encoding haloaromatic catabolic enzymes and the construction of hybrid pathways for substrate mineralization. In Genetic Control of Environmental Pollutants, pp. 47-80. Edited by G.S. Omenn \& A. Hollaender. New York \& London: Plenum Press.

Winstanley, C., Morgan, J. A. W., Pickup, R. W., Jones, J. G. \& Saunders, J. R. (1989). Differential regulation of lambda $p_{\mathrm{L}}$ and $p_{\mathrm{R}}$ promoters by a $c \mathrm{I}$ repressor in a broad-host range thermoregulated plasmid marker system. Appl Environ Microbiol 55, 771-777.

Received 17 December 1993; revised 3 February 1994; accepted 7 February 1994. 